\title{
The importance of the management of small reed patches for the conservation of endangered passerine birds linked to wetlands
}

\begin{abstract}
Reed patches around wetlands have been proved to be important to enhance dispersal of vertebrates, particularly medium-size birds. However the importance for small size endangered passerine birds, some of them totally or partially endangered (e.g. Acrocephalus paludicola, Acrocephalus melanopogon, Emberiza schoeniclus, Panurus biarmicus) is not completely assessed. This mini-review highlights some physiological mechanisms used for reed bed specialists to move in reed patches and emphasizes the importance of management peripheral areas of wetlands to ensure dispersal.
\end{abstract}

Keywords: endangered passerines, management, small reed patches, wetlands
Volume I Issue 2 - 2017

Ignacio García Peiró

Department of Ecology \& Hidrology, University of Murcia, Spain

Correspondence: Ignacio García Peiró, Department of Ecology \& Hidrology, Faculty of Biology, E-30100, University of Murcia, Spain, Tel 0034965451777 ,

Email ignacio.garcia.peiro@gmail.com

Received: October 03, 2017 | Published: November 14, 2017

\section{Introduction}

Wetlands are complex systems where the interaction among biotic and a biotic components provides a surplus of values, functions and environmental services. The value of wetlands has evolved from certain species, communities and habitats, towards a global scenario which reflects in similar importance the group of components and the relationship of these with the ecosystem. ${ }^{1,2}$

From the particular case of birds linked to wetlands a great amount of research effort and monitoring has been focused mainly towards birds of medium size (e.g. Anatidae, Ardeidae, and Charadriidae: ${ }^{3-7}$ Regarding general studies focused on management of wetlands, the orientation has mainly favored those actions directed towards aquatic birds linked to the interphase among water and reed ${ }^{8,9}$ and the research and experimentation of the reed management and other emergent plants seem to be oriented to its control with the aim to increase its biodiversity, ${ }^{10-12}$ and, in the case of birds, to produce aquatic habitats or to keep the suitable proportions among vegetation and free water, so this management form have traditionally favored aquatic bird families like ducks or coots. ${ }^{13}$ However until the last 1990's not emerge the studies on small birds linked to the marsh and reeds, as the studies analyzing its communities ${ }^{14,15}$ and also those referred to the biology, ecology and conservation of its species. ${ }^{16,17}$ Due to the implementation of ringing stations with Constant Effort Sites at wetlands, many pioneer studies have been performed from the beginnings of the present century. ${ }^{18-21}$

In contrast, the research about habitat management of endangered palustrine small birds (e.g. Acrocephalus paludicola, Acrocephalus melanopogon, Emberiza schoeniclus, Panurus biarmicus 22-24,25,26 and particularly the study of evolutionary processe ${ }^{27-29}$ carried out in its habitats where the habitat patches play an important role for the conservation of this species ${ }^{30,31}$ is still scarce. The evolutionary outcomes can result excellent studies on local movements among landscape patches, for example, in the context of metapopulations. ${ }^{32,33}$

In this sense habitat management for biodiversity conservation is based in the species-area relationship and the intermediate disturbance hypothesis. ${ }^{34}$ Management of larger habitat patches should conserve more species and species diversity is maximized when ecological disturbance is at intermediate levels. ${ }^{35}$ For example, in reed habitats, under appropriate long-term management, the homogeneous structure of the reed habitat breaks up forming a more heterogeneous structure, which provides more suitable small habitats for a wider spectrum of species. ${ }^{36}$ Management of patches of reeds varies within species and studies have come to show that abundance and diversity of songbird reed bed species is highest in unmanaged (e.g unburned) than managed (e.g. burned) areas. ${ }^{37,38}$

Intraspecific and interspecific differences are found in these habitats and they are based on an ecomorphological perspective. ${ }^{39,40}$ Suboptimal areas support birds of lesser ages and minor condition and size (females and juveniles) ${ }^{41}$ while patches inside of unmanaged habitats are used as sources and support more birds with more age and better condition..$^{42}$ Marginal reed habitats are thus used for foragertransient birds ${ }^{43}$ and with interspecific differences in morphology, migratory behavior and foraging activity. ${ }^{44}$ Then, several factors as ability to find food resources, dominance status, or energetic constraints related to flight, can equally determine its morphological adjustments ${ }^{45}$ and movements inside or among reed patches.

\section{Conclusion}

Small reed patches are an important process for the development of globally threatened or endangered small populations of specialized reed birds ensuring dispersal (e.g. Acrocephalus paludicola, ${ }^{33}$ Panurus biarmicus ${ }^{29}$ ). In order to facilitate the increase physiological constraints of these passerine birds enhancing dispersal is need to manage suboptimal pioneer areas of reed for the growth of seed plants and the increase diversity of insects by means of mixed plots of cutted and uncutted bushes, reeds and another medium high marsh trees. Also is emphasized the importance of intertidal wetlands in terms opportunities of some physiological birds processes as moult for some not threatened palustrine birds (e.g. Luscinia svecica) ${ }^{46}$ Then, is highlighted the implementation and management of smallmarginal areas of wetlands around great areas providing to increase the diversity of reed-dwelling-marsh passerines. ${ }^{47}$

\section{Acknowledgements}

None. 


\section{Conflict of interest}

The author declares no conflict of interest.

\section{References}

1. Amezaga JM, Santamaría L, Green AJ. Biotic wetland connectivitysupporting a new approach for wetland policy. Acta Oecologica. 2002;23(3):213-222.

2. Telleria JL. Conservation Biology: why conserve species? In: Valladares F, editor. Unity in diversity: reflections under legacy of Ramón Margalef. Spain: BbVA Fiundacion; 2008. p. 260-290.

3. Amat JA. Las poblaciones de aves acuáticas en las lagunas andaluzas: composición y diversidad durante un ciclo anual. Ardeola. 1984;31:6179.

4. Paracuellos M. Fenología anual de la ornitofauna en las salinas de Guardias Viejas (Almería). Calidad ornítica. Alytes. 1993;6:317-333.

5. Enciso JP, Paracuellos M. Dinámica estacional de la comunidad de aves acuáticas en los humedales del levante almeriense (SE ibérico) Caracterización e importancia ornítica provincial. Oxyura. 1997;9:24 43.

6. Navarro JD, Robledano F. La cerceta pardilla en España. Serie Técnica. Spain: ICONA; 1995.

7. Fuentes C. Ecología de la Cerceta pardilla (Marmaronetta angustirostris) y de la Malvasía cabeciblanca (Oxyura leucocephala) en los humedales del Baix Vinalopó, Alicante. Spain: PhD Thesis, University of Alicante; 2005.

8. Burgess ND Evans CE. The Management of reed beds for birds. UK RSPB; 1989

9. Moss B. The Norfolk Broadland: Experiments in the restoration of a complex wetland. Biological Reviews. 1983;58(4):521-561.

10. Gryseels M. Nature management experiments in a relict reed marsh. I: Effects of winter cutting. Biological Conservation. 1989;47(3):171-193.

11. Ailstock MS, Norman CM, Bushmann PJ. Common Reed Phragmites australis: Control and effects upon biodiversity in freshwater nontidal wetlands. Restoration Ecology. 2001;9(1):49-59.

12. Weller MW. Management of freshwater marshes for wildlife. In: Good RE, editor. Freshwater Wetlands. USA: Academic Press; 1978. p. $267-$ 284

13. Castany J. El carricerín real (Acrocephalus melanopogon) en el PN. del Prat de Cabanes-Torreblanca. Spain: PhD Thesis, University of Valencia; 2003.

14. Torres JA, Cárdenas AM, Bach C. Estudio de la comunidad de Passeriformes de la laguna de Zoñar (Córdoba, España). Naturalia Hispánica. 1983;24:1-40.

15. Grandío JM. Comparación del peso y su incremento, del tiempo de estancia y de la abundancia del Carricerín común (Acrocephalus schoenobaenus) entre dos zonas de la marisma de Txingudi (Norte de España). Ardeola. 1998;45(2):137-142.

16. Molina J, Hódar JA, Camacho I. Diet of Cetti's Warblers Cettia cetti (Temminck, 1820) in a locality of southern Spain. Ardeola. 1998;45(2):217-220.

17. Cárdenas AM, Torres JA, Bach C. Estudio comparado del régimen alimentario de Acrocephalus arundinaceus y A. scirpaceus en la laguna Zoñar. Ardeola. 1983;30:33-45.

18. Peiró IG, Esteve MA. Ecología de los Passeriformes del carrizal del Parque Natural del Fondo. USA: Instituto de Cultura Juan Gil Albert; 2001
19. Bermejo A. Migratología, estructura y dinámica poblacional de Passeriformes asociados a vegetación de ribera. Ph Thesis. Spain: Autonomous University of Madrid; 2004.

20. Bermejo A, De La Puente J. Wintering and Migration of Bluethroat Luscinia svecica in Central Spain. Ardeola. 2004;51(2):285-296.

21. Neto JM. Annual dynamics of reed bed passerines in ria de Aveiro, Portugal, assessed by standardized mist-netting. Airo. 2003;13(1):17-29.

22. Atienza, JC Copete JL. Escribano Palustre Iberoriental/Escribano Palustre Iberoccidental. In: Madroño A, editor. Libro Rojo de las Aves de España. Spain: Ministerio de Medio Ambiente-SEO/Birdlife; 2004. p. 378-379.

23. López G, Monrós J. Bigotudo (Panurus biarmicus). In: Madroño A editor. Libro Rojo de las Aves de España. Spain: MMA-SEO/Birdlife; 2004. p. 341-344.

24. Bairelin F. Habitat selection and associations of species in European passerine birds during southward, postbreeding migrations. Ornis Scandinavica. 1982;14(3):239-245.

25. Peiró IG, Pagani-Núñez E, In prep. The Bearded Reedling Panurus biarmicus in Iberia: insights from an incipient spread.

26. Poluin B, Lefebvre G, Mauchamp A. Habitat requirements of passerines and reed bed management in southern France. Biological Conservation. 2002;107(3):315-325.

27. Winkler H, Leisler B. Morphological Aspects of Habitat Selection in Birds. In: Cody ML, editor. Habitat selection in Birds. USA: Academic Press; 1985. p. 415-434.

28. Leisler B, Catchpole CK. The evolution of polygamy in Europen Reed Warblers of the genus Acrocephalus; a comparative approach. Ethology, Ecology and Evolution. 1992;4(3):225-243.

29. Leisler B, Ley HW, Winkler H. Habitat, behaviour and morphology of Acrocephalus warblers: an integrated analysis. Ornis Scandinavica. 1989;20(3):181-186.

30. Beemster N, Troost E, Platteuw M. Early successional stages of Reed Phragmites australis vegetations and its importance for the Bearded Reedling Panurus biarmicus in Oostvaardersplassen, The Netherlands. Ardea. 2010;98(3):339-354.

31. Peiró IG. The behavioural ecology, local population dynamics and conservation of the Bearded Reedling Panurus biarmicus in "El Hondo Natural Park" (SE Spain). Ecology \& Evolutionary Biology. 2007;2(2):25-33.

32. Báldi A, Kisbenedék T. Bird species numbers in an archipelago of reeds at Lake Velence, Hungary. Global Ecology and Biogeography. 2000;9:451-461.

33. Marin G, Marchesini M, Tiloca G, et al. DNA fingerprinting fails to reveal inbreeding in a small, closed population of Bearded Tits (Panurus biarmicus L.). Ethology, Ecology and Evolution. 1994;6(2):243-248.

34. Paracuellos M. Estructura y conservación de las comunidades de aves en humedales del Sudeste iberico (Almería, España). PhD Thesis. Spain: University of Almería; 2001. p. 1-184.

35. Schwilk DW, Keeley JE, Bond WJ. The intermediate disturbance hypothesis does not explain fire and diversity pattern in fynbos. Plant Ecology. 1997;132(1):77-84.

36. Poulin B, Duborper E, Lefebvre G. Spring stopover of the globally threatened Aquatic warbler Acrocephalus paludicola in Mediterranean France. Ardeola. 2010;57:167-173.

37. Peiró IG. Estudios ornitológicos basados en la gestión del hábitat de los Passeriformes del carrizal en el Parque Natural de El Hondo. PhD Thesis. Spain: University of Murcia; 2006.S 
38. Mérő TO, Lontay L, Szabolcs L. Habitat management varying in space and time: the effects of grazing and fire management on marshland birds. Journal of Ornithology. 2015;156(3):579-590.

39. Kennerley P, Pearson D. Reed and Bush Warblers. UK: Christopher Helm Limited; 2010.

40. Leisler B, Schulze-Hagen K. The reed warblers. Diversity in a uniform bird family. Netherlands: KNNV Publishing; 2011.

41. Peiró IG. Are juveniles of Bearded Tits Panurus biarmicus becoming to be more mobile against adults in El Hondo Natural Park? A longitudinal study. In: Robledano F, editor. Resúmenes XX Congreso de Anillamiento Científico de Aves. Spain; 2017. p. 69-70.

42. Sansano PM, González F, Lopez G. Ocupación de hábitats óptimos y suóptimos por el carricero común (Acrocephalus scripaceus) en el Parque Natural de El Hondo y su entorno. In: Robledano, editor. Resúmenes XX Congreso de Anillamiento Cientifico de Aves. Spain; 2017. p. 68-69.
43. Poulin B, Lefebvre G, Metref S. Spatial distribution of nesting and foraging sites of two Acrocephalus warblers in a Mediterranean reedbed. Acta Ornithologica. 2000;35(1):117-121.

44. Neto JM, Gordinho L, Belda EJ, et al. Phenotypic Divergence among West European Populations of Reed Bunting Emberiza schoeniclus: The Effects of Migratory and Foraging Behaviours. PlosOne. 2013;8(5):e63248.

45. Senar JC, Camerino M, Uribe F. Body mass regulation in resident and transient wintering siskins Carduelis spinus. Etología. 2001;9:47-52.

46. Musseau R, Beslic S, Kerbiriou Ch. Importancia de los humedales intermareales para el ruiseñor pechiazul Cyanecula svecica namnetum endémico de la costa francesa e implicaciones de conservación en el contexto del cambio global. Ardeola. 2017;64(2):325-345.

47. Jiménez J, Moreno-Opo R, Carrasco M, et al. Estimating the abundance and habitat selection of conservation priority marsh-dwelling passerines with a double-observer approach. Ardeola. 2015;62(2):269-281. 